\title{
Cocoa Seed Shelf-Life and Seed Germination as Influenced by Pectin-Coat Application
}

\author{
Rosyidatul Putri Munawaroh ${ }^{11}$, Indah Anita-Sari ${ }^{2 *}$, and Sri Rahayu ${ }^{1)}$ \\ ${ }^{1)}$ Study Program in Seed Production Technique, Jember State Polytechnic, Jember, Indonesia \\ ${ }^{2)}$ Indonesian Coffee and Cocoa Research Institute, Jl. P.B. Sudirman 90, Jember, Indonesia \\ ${ }^{*}$ Corresponding author: indah.anita@gmail.com \\ Received: 2 April 2019 / Accepted: 20 May 2020
}

\begin{abstract}
The time difference between the availability and the needs of cocoa seeds causes the national needs can not be fulfilled. Recalcitrant cocoa seed cannot be stored for a long time, germinating seeds during the storage process change in abnormal seedling growth. One of seed technology to maintain the seed quality during the storage is seed coating. Pectin is one of the compounds that can be used for coating on several commodities, also possible to be used on cocoa seeds. The study was conducted at Plant Breeding Laboratory of Indonesian Coffee and Cocoa Research Institute, Jember. The experiment used a factorial randomized completely block design consisting of two factors. The first factor were concentration of pectin $0 \%$ (control), $1 \%$, and $3 \%$, while the second factor were shelflife of 1 week, 2 weeks, and 3 weeks. Each treatment combination was repeated three times. The results showed that pectin-coat treatment could keep cocoa seeds from germinating for 3 weeks but unable to maintain the quality of seeds during storage.
\end{abstract}

Keywords: Cocoa seeds, pectin-coat, shelf-life of seeds, germination

\section{INTRODUCTION}

A certified cocoa seed provision is the major key in increasing cocoa production. National cocoa seed demand is quite high ranging from 15-22 million seeds per year (Anita-Sari \& Susilo, 2015). The problem is the mismatch between harvest season and the need for seeds so that many seeds cannot be used as seeds but only as cocoa beans. Recalcitrant cocoa seeds cannot be stored for a long period, meanwhile the cocoa seed distribution process is carried out for all regions in Indonesia. Many seeds arrive at the destination in a germinated condition so that the roots grow bent and easily damaged when planted. Eventually, the seeds grow abnormally and affect the process of cocoa cultivation. After removed from pods without treatment, cocoa seed stay alive only 3-4 days, then will deteriorate. The deterioration process of cocoa seeds can be seen from the decrease in seed germination and seed vigor.

Many studies have been conducted to overcome the deterioration of cocoa seeds during storage, such as seed invigoration techniques and modification of seed storage technique. Modification of seed storage techniques is considered more effective than seed invigoration. A study to maintain the viability and vigor of cocoa seeds by placing the seeds in sawdust, showed that stored for 5 days using $40 \mathrm{~g}$ of sawdust had a seed viability 
of $93.3 \%$ (Sumampouw, 2010). However, when viewed from the efficiency of the storage room, using sawdust is bulky. The use of sawdust in the packaging is less efficient in the distribution process because space to load more seeds is occupied by sawdust instead. Besides, unsterilized sawdust has the potential to be a source of disease.

Another study conducted by Nurahmi et al. (2010) on benlate fungicide treatment and polypropylene plastic packaging usage showed that the interactions between benlate concentration of $0.65 \%$ and perforated polypropylene plastic packaging were able to mantain viability after 15 -days storage and simultaneous growth after 30-days storage. Pancaningtyas (2013) developed a cocoa seed storage method that can extend dormancy time by freezing (cryopreservation). Seed delivery was successfully carried out, and the seeds arrived at the destination location in a delayed germination condition without decreasing viability and not changing the genetic traits of the plant. The cryopreservation method has a weakness that requires expertise and expensive costs.

A technology to increase the shelf-life of seeds is by seed coating. Seed coating is a method to coat seeds using certain materials with specific purposes. The application of seed coatings has been done for horticultural and food crop seeds. Sari et al. (2013) tried seed coating technology as a substitute for peanut pod husk to see its effect on seed viability during 16 weeks of storage. The results showed that the seeds with seed coating treatment had a better vigor index of $40.2 \%$ and $45.8 \%$ compared to peeled seed without seed coating of $28.2 \%$. Other seed coating study (Agustiansyah, 2016) also conducted on soybean seeds reported that soybean seeds can be stored for three months using seed coating. Madyasari et al. (2017) tried seed coating on chili seeds to maintain seed viability for 24 weeks of storage. Seed coating technology has prospects for cocoa seeds, considering that cocoa seeds have high water content, which means the risk of germination and or high water loss. Some materials that can be used as seed coatings are chitosan, arabic gum, carboxyl methylcellulose (CMC) and pectin (Anisa et al., 2017).

Pectin is widely used as an edible coating for food and fruit coating. The main function of pectin is to block mass transfer such as oxygen, light, lipids, and other solutes so that food lasts longer. Pectin seed coating was used to prevent cacao seeds germination during storage and keep the growth of seedlings in line with the standard, namely the water content of 30-40\% and the germinated percentage of $80 \%$ (Kementan, 2013).

\section{MATERIALS AND METHODS}

This study was conducted in October 2017 to March 2018 at the Plant Breeding Laboratory and Green House of Indonesian Coffee and Cocoa Research Institute, Jember. The half-sib of Sulawesi 01 cocoa seeds were used. The experimental design used a factorial randomized completely block design which consisted of 2 factors, each of which consisted of 3 levels. The first factor was concentration of pectin consisting of $0 \%$ (control), $1 \%$ pectin, and $3 \%$ pectin. The second factor was seed shelf-life of one week, two weeks, and three weeks. The study consisted of 9 treatment combinations that were repeated three times so that in total there were 27 experimental units. The data were processed statistically using analysis of variance. If the results show a significant effect, then it will be continued with the Duncan multiple range test at the 5\% level. 
The mature cocoa pod of Sulawesi 1 clone was collected from Kaliwining Experimental Station of Indonesian Coffee and Cocoa Research Institute. Harvesting was done at 08.00-09.00 AM, then harvested pods were broken down to take cocoa seeds. The cocoa seed coating using pectin was done in several stages. Firstly, pectin powder was weighed according to the treatment $1 \%(1 \mathrm{~g})$, and $(3 \%) 3 \mathrm{~g}$. Pectin powder was mixed with $100 \mathrm{~mL}$ of water and put into the beaker glass. The mixture of pectin powder and water was then heated on a hot plate at $250^{\circ} \mathrm{C}$ while being stirred using a magnetic stirrer. A homogeneous pectin solution was then cooled.

The second step was removing the cocoa pulp using sawdust. The seeds were then soaked in a Dithane fungicide solution with a dose of $2 \mathrm{~g} / \mathrm{L}$ for about 5 minutes to protect the seeds from fungal attack during storage, then the seeds were air-dried. The cool pectin solution is then used to coat the cocoa seeds by dipping for about five minutes to let the coat solution soaks into the seed. The seeds were air-dried. The pectin-coated cocoa seeds were then stored in airtight polyethylene plastic bags using sealer. Cocoa seeds were stored in room temperature of $24^{\circ} \mathrm{C}$. The storage was carried out following the treatment of seeds, namely 1 week, 2 weeks, and 3 weeks.

Observations were carried out on seed viability, growth, simultaneous seed growth, seed weight loss, and seed water content reduction rate (Rahardjo, 2011).

\section{Seed Weight Loss}

Cocoa seeds were weighed before pectincoat treatment and after storage. The seeds were weighed as many as 50 seeds. Seed weight loss $(\%)$ was calculated using the following formula:

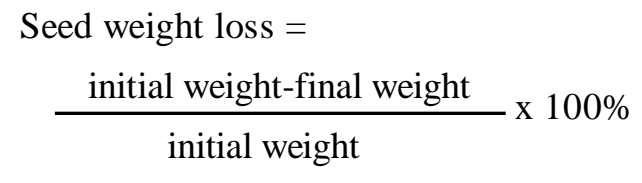

\section{Seed Moisture Content Loss}

As recalcitrant seeds, it is necessary to understand the effect of pectin coating material on the moisture content of cocoa seeds before and after storage. Stages to measure the moisture content of cocoa seeds are weighing the petri dish and its lid (W1), weighing 10 cocoa seeds and petri dish before being heated (W2), weighing the seeds and petri dish containers after being heated at $130^{\circ} \mathrm{C}$ for 50 minutes (W3) and weighing the seeds and petri dish after being heated at $130^{\circ} \mathrm{C}$ for 10 minutes (W4). The formula was as follows:

a. The first heating calculation formula

$$
\mathrm{S} 1=\frac{\mathrm{w} 2-\mathrm{w} 3}{\mathrm{w} 2-\mathrm{w} 1} \times 100 \%
$$

b. The second heating calculation formula

$$
\mathrm{S} 2=\frac{\mathrm{w} 3-\mathrm{w} 4}{\mathrm{w} 2-\mathrm{w} 1} \times 100 \%
$$

c. The moisture content of coooa seed formula

$$
\mathrm{MC}=\mathrm{S} 1+\mathrm{S} 2-\frac{\mathrm{S} 1-\mathrm{S} 2}{100}
$$

Moisture content loss of cocoa seeds was observed to see the effect of pectin seed coating on the seed moisture content during the storage. The percentage of moisture content loss of cocoa seeds was calculated from the difference in moisture content before treatment (initial MC) and moisture content after storage (final MC), the formula was as follows:

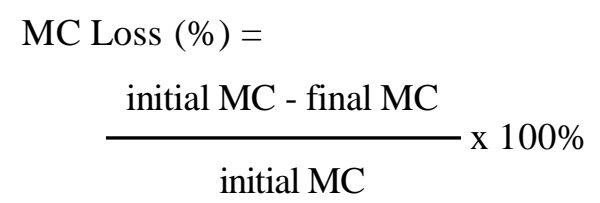




\section{Seed Germination Percentage}

Seed germination (GP) was the ability of seeds to grow into seedlings until the end of the observation period, which was the $12^{\text {th }}$ day after sowing. The seeds were germinated in the sand media by 50 seeds. The formula for germination of seeds was as follows:

$\mathrm{GP}=$

The number of germinating seeds

The number of germinated seeds $\times 100 \%$

\section{Seed Growth Rate}

The seed growth rate (GR) is determined using the percentage of normal sprouts per day, calculated from the emergence of normal sprouts until the $12^{\text {th }}$ day. The formula used to determine the speed of growth of cocoa seeds that have been treated with pectin-coat and the shelf-life of the seeds are:

GR =

$$
\sum_{\mathrm{i}-1}^{\mathrm{n}} \frac{\% \text { normal sprouts at day-i }}{\text { period at day-i }}
$$

\section{Germination Uniformity}

Germination uniformity (GU) of seeds was observed from the percentage of normal strong germinated seeds between observation day I (first count) and observation day II (final count). The first observation was on the $4^{\text {th }}$ day and the last observation was on the $10^{\text {th }}$ day, so to calculate the germination uniformity of seeds was done on the $7^{\text {th }}$ day. The formula was as follows:

$\mathrm{GU}(\%)=$

$\underline{\text { Strong normal sprouts at the } 7^{\text {th }} \text { days }} \times 100 \%$

Number of germinated seeds

\section{RESULTS AND DISCUSSION}

\section{Physiological Quality}

Physiological quality of seeds is a metabolic process in seeds that involves enzymes, biochemical reactions, and respiration of seeds. The cocoa seeds were germinated in a sandbox media for 12 days to observe the physiological quality of the seed including germination percentage (GP), growth rate (GR), and germination uniformity (GU).

Germination of recalcitrant seeds such as cocoa tends to be fast. Cocoa seeds will germinate within 3-4 days, but if the seeds do not get good storage treatment, the seeds will lose their germination after 10-15 days (Baharudin et al., 2010). Germinated seeds during the shipping process decrease the quality of seedlings (deterioration). Pectin was used as a seed coating material to prevent the process of seed germination during shipment so that the quality of the seeds is maintained. The ability of cocoa seeds to germinate after a period of storage is important to be considered, because that cocoa seeds will be used as

Table 1. Effect of pectin-coat and shelf-life of seeds on physiological quality of cocoa half-sib of Sulawesi 01 clone

\begin{tabular}{|c|c|c|c|}
\hline Treatment & GP $(\%)$ & GR $(\%)$ & $\mathrm{GU}(\%)$ \\
\hline $0 \%$ Pectin +1 week & $97.33 \mathrm{c}$ & $20.09 \mathrm{~d}$ & $66.67 \mathrm{e}$ \\
\hline $0 \%$ Pectin +2 weeks & $94.00 \mathrm{c}$ & $20.36 \mathrm{~d}$ & $61.33 \mathrm{de}$ \\
\hline $0 \%$ Pectin +3 weeks & $58.67 \mathrm{~b}$ & $11.14 \mathrm{ab}$ & $54.00 \mathrm{~cd}$ \\
\hline $1 \%$ Pectin +1 week & $64.00 \mathrm{~b}$ & $14.64 \mathrm{bc}$ & $48.67 \mathrm{bc}$ \\
\hline $1 \%$ Pectin +2 weeks & $52.67 \mathrm{~b}$ & $8.84 \mathrm{a}$ & $40.67 \mathrm{ab}$ \\
\hline $1 \%$ Pectin +3 weeks & $48.67 \mathrm{ab}$ & $9.08 \mathrm{a}$ & $42.67 \mathrm{ab}$ \\
\hline $3 \%$ Pectin +1 week & $96.67 \mathrm{c}$ & $25.61 \mathrm{e}$ & $68.00 \mathrm{e}$ \\
\hline $3 \%$ Pectin +2 weeks & $90.00 \mathrm{c}$ & $18.13 \mathrm{~cd}$ & $60.67 \mathrm{de}$ \\
\hline $3 \%$ Pectin +3 weeks & $42.67 \mathrm{a}$ & $8.68 \mathrm{a}$ & $39.33 \mathrm{a}$ \\
\hline
\end{tabular}


planting materials. Cocoa seeds quality must have a minimum germination percentage of 80\% (Kementan, 2013).

Table 1 shows the effect of pectin-coat and shelf-life of seeds on the germination percentage of the seeds from each different treatment. The interaction between $0 \%$ pectin concentration and shelf-life of one week (control) was able to maintain the germination of cocoa seeds higher than other treatments by $97.3 \%$. The treatment of $1 \%$ pectin-coat makes the deterioration rate increase, presumably because the $1 \%$ pectin solution tends to be aqueous. High solvent content of pectin causes the cocoa seeds to imbibe and trigger an increased metabolic process. Whereas the $3 \%$ pectin solution tends to be thicker and able to form a protective layer on the surface of the seed. The treatment of $3 \%$ pectin seed coating can maintain the quality of cocoa seeds following the standard for up to two weeks of storage which may due to the hygroscopic nature of pectin that can bind water so that the water transfer from the environment into the seeds or vice versa can be minimized. Pectin has been used as a fruit coating material, as reported by Susilowati et al. (2017). The use of $3 \%$ pectin as an edible coating material can keep tomatoes fresh for up to 21 days of storage. However, when seed coated with pectin the case is different, the seed has an embryo that has the opportunity to become a new plant. Pectin is suspected to affect the performance of the embryo in the process of seed germination that have gone through the storage process.

The growth rate is the normal growth of cocoa sprouts observed every day for 12 days. Seeds having high growth rate are those that can reactivate cells and metabolize quickly in optimum environmental conditions. A seed that has a high growth rate indicates a vigor seed, meaning that the seed can grow in suboptimum environmental conditions. Table 1 shows the effect of pectin-coat and seed shelf- life on the seed growth rate of each treatment. The interaction between the concentration of $3 \%$ pectin and the shelf-life of one week of the cocoa seed made the growth rate of the seed higher than other treatments of $25.6 \%$. This is presumably because $3 \%$ pectin of seed coating can coat the surface of the seed and reduces the risk of water loss and food reserves from the seeds. The seed food reserves stored for one week are still sufficient to be immediately used in the process of seed germination (Raharjo et al., 2010). The germination viability of the cocoa seeds resulted from the interaction between 3\% pectin and the shelf-life of the seeds for one week in Table 3 is high by $96.7 \%$, so it affects the seed growth rate which is also high (Lesilolo et al., 2012).

The germination uniformity of cacao seeds is the ability of cacao seeds to grow uniformly into normal and strong seeds on the $7^{\text {th }}$ day of germination. Normal cocoa seeds are characterized with broken cotyledons and lifted above ground level, good roots (perpendicular primary root and secondary roots at least 2), the length of epicotyl and hypocotyl is balanced and not broken, and the plumules are perfect with green leaves. While the characteristics of abnormal seedlings are closed cotyledons, short roots, twisted hypocotyl or epicotyl, stunted, rotating plumules, and deformed sprouts. The germination uniformity of seeds is one way to determine the rate of seed growth as a parameter of seed resistance to competition in field (vigor). Table 1 shows the effect of pectin seed coating and the shelf-life of seed on the germination uniformity of seed from each treatment. Number of strong normal seeds on the $7^{\text {th }}$ day was mostly produced by the interaction between $3 \%$ pectin and the seed shelf-life of one week by $68.0 \%$, the same effect was also shown by the interaction of $0 \%$ pectin and the seed shelf-life of one week by $66.7 \% .3 \%$ pectin seed coating can coat the 
surface of the seeds for one week so that the respiration process causing food reserves to be used can be suppressed. The germination uniformity of seeds is influenced by seed vigor as seen from the high rate of seed growth (Lesilolo et al., 2013). The interaction between $3 \%$ pectin and the seed shelf-life of one week produced vigorous seed compared to other treatments. The cocoa seeds came from seeds that have high growth rate. Whereas the seeds growing not uniformly will stunted growth because there is a competition between individuals in a nursery area.

\section{Physical Quality}

Cocoa half-sib of Sulawesi 01 seeds are classified as recalcitrant and large-sized seeds. Newly harvested cacao seeds are heavy because the moisture content and the food reserves are in optimal conditions. The initial moisture content of newly harvested seeds is $35-43 \%$, this caused the cocoa seeds to continue their metabolic processes even when they are in dorman condition. High seed water content causes the seed shelf life to be low due to the high respiration process in seeds during storage (Anisa et al., 2017). The treatment of pectin seed coating and the seed shelf-life aim to prevent the loss of seed weight and the loss rate of seed moisture content during storage.

The weight of the cocoa seeds in this study was observed before and after storage to see the percentage of seed weight loss, while the seed water content loss was observed by calculating the percentage of seed water content before seed coating treatment and after the seeds passed through pectin seed coating and shelf-life seed.

\section{Weight Loss}

Table 2 show the effect of pectin-coat and seed shelf-life on seed weight loss of each treatment. Cocoa seeds stored for a certain period will continuously undergo metabolic processes that cause a decrease in seed quality (deterioration), as shown by the loss of seed weight. Pectin was used as a seed coating material to reduce the risk of weight loss during cocoa seed storage.

The interaction between $1 \%$ pectin and the seed shelf-life of 1 week showed the lowest effect of seed weight loss $(2.15 \%)$ compared with other treatment interactions (Table 2). This might be due to the pectin concentration of $1 \%$ forms a semipermeable layer on the seed surface for one week of storage so that the risk of losing food reserves in the process of respiration and transpiration can be minimized. Cocoa seeds survive during certain storage processes by metabolism absorbing oxygen to make use of organic material in the seeds to support the survival of the seeds during storage, while the rest is released in form of carbon dioxide and water vapor. The higher the weight loss

Table 2. Effect of pectin-coat and shelf-life of seeds on weight loss and moisture content of cocoa half-sib of Sulawesi 01

\begin{tabular}{|c|c|c|}
\hline Treatment & Seed weight loss $(\%)$ & Moisture content loss (\%) \\
\hline $0 \%$ Pectin +1 week & $7.46 a b$ & $38.69 \mathrm{a}$ \\
\hline $1 \%$ Pectin +1 week & $2.15 \mathrm{c}$ & $3.02 \mathrm{~cd}$ \\
\hline $3 \%$ Pectin +1 week & $11.93 \mathrm{a}$ & $23.49 \mathrm{~b}$ \\
\hline $0 \%$ Pectin +2 weeks & $4.42 \mathrm{bc}$ & $6.03 \mathrm{~cd}$ \\
\hline $1 \%$ Pectin +2 weeks & $6.01 \mathrm{bc}$ & $9.27 \mathrm{~cd}$ \\
\hline $3 \%$ Pectin +2 weeks & $8.60 \mathrm{ab}$ & $13.73 \mathrm{c}$ \\
\hline $0 \%$ Pectin +3 weeks & $4.37 \mathrm{bc}$ & $7.89 \mathrm{~cd}$ \\
\hline $1 \%$ Pectin +3 weeks & $8.30 \mathrm{ab}$ & $4.19 \mathrm{~cd}$ \\
\hline $3 \%$ Pectin +3 weeks & $5.12 \mathrm{bc}$ & $4.36 \mathrm{~cd}$ \\
\hline
\end{tabular}


of seeds, the more food reserves in the seeds lose.

One percent pectin concentration in form of a thick solution such as gel coating the surface of the seed and reducing the rate of weight loss during one week of storage. The results of this study are in line with the study of by Alexandra \& Nurlina (2014) that the use of $1 \%$ pectin as an edible coating material for coating songhi oranges is the most optimal in preventing respiration for 10 days of storage.

\section{Moisture Content Loss}

The results show the effect of pectin-coat and the seed shelf life on the loss of seed moisture content of treatment (Table 2). Cocoa seeds classified as recalcitrant seeds have a water content of $30-40 \%$ and tend to do respiration during storage, meanwhile the moisture content of cocoa seeds will affect the viability of seeds. Pectin-coat is used to maintain the moisture content of the seed for several periods of shelf-life by coating the surface of the seed; this is expected to reduce the rate of moisture loss from inside the seed.

Table 2 shows that the interaction between $1 \%$ pectin concentration and the shelf-life of one week was able to suppress the rate of moisture content loss lower than other treatments by $3.02 \%$. This shows that the concentration of $1 \%$ pectin-coat can reduce the risk of water loss during the shelf-life of one week. One percent pectin concentration coats the surface of the cocoa seed to form a semipermeable layer so that the surface pores of the cocoa seed are increasingly closed and suppress the rate of loss of seed moisture content in the respiration process. Seed respiration also release carbon dioxide and water vapor during the storage, the longer the shelf-life, the higher the rate of loss of seed moisture content. The use of pectin concentration of $1 \%$ as an edible coating material can reduce the water content loss in the red guava fruit (Jacoeb et al., 2014)

\section{CONCLUSIONS}

Three pectin concentration can be used as a seed coating material but it is still less efficient considering that the effect is insignificantly different from the control. The longer of shelf-life of seeds cause the higher of deterioration rate of seeds. The treatment could keep cocoa seeds from germinating for three weeks but unable to maintain the quality of seed during storage.

\section{REFERENCES}

Agustiansyah (2016). Efek bahan coating dan aditif pada viabilitas dan vigor benih kedelai (Glycine max L. Merril) selama penyimpanan. Prosiding Seminar Nasional Perhorti dan Peragi Makassar, 14 November 2016.

Alexandra, Y. \& Nurlina (2014). Aplikasi edible coating dari pektin jeruk Songhi Pontianak (Citrus nobilis var Microcarpa) pada penyimpanan buah tomat. Jurnal Kimia Khatulistiwa, 3, 11-20.

Anisa, N.; F. Kusmiyati \& K. Karno (2017). Pelapisan benih melon (Cucumis melo L.) dengan ekstrak kulit jeruk untuk mempertahankan mutu fisiologis benih selama penyimpanan. Journal of Agro Complex, 1, 111-119.

Anita-Sari, I. \& A.W. Susilo (2015). Peluang dan tantangan perbenihan kakao di Indonesia. Warta Pusat Penelitian Kopi dan Kakao Indonesia, 27, 6-13.

Baharudin, S.I.; M.R. Suhartanto \& A. Purwantara (2010). Pengaruh lama penyimpanan dan perlakuan benih terhadap peningkatan vigor benih kakao hibrida. Jurnal Pengkajian Pengembangan Teknologi Pertanian, 13, 73-84.

Jacoeb, A.M.; R. Nugraha \& S. Utari (2014). Pembuatan edible film dari pati buah 
lindur dengan penambahan gliserol dan karaginan. Jurnal Pengolahan Hasil Perikanan Indonesia, 17, 14-21.

Kementan (2013). Peraturan Menteri Pertanian Tentang Standar Operasional Prosedur (SOP) Penetapan Kebun Sumber Benih, Sertifikasi Benih, dan Evaluasi Kebun Sumber Benih Tanaman Kakao (Theobroma cacao L.). Kementerian Pertanian. Jakarta.

Lesilolo, M.K.; J. Patty \& N. Tetty (2012). Penggunaan desikan abu dan lama simpan terhadap kualitas benih jagung (Zea mays L.) pada penyimpanan ruang terbuka. Journal Agrologia, 1, 51-59.

Lesilolo, M.K.; J. Riry \& E.A. Matatula (2013). Pengujian viabilitas dan vigor benih beberapa jenis tanaman yang beredar di pasaran kota Ambon. Journal Agrologia, 2, 1-9.

Madyasari, I.; C. Budiman; Syamsuddin; D. Manohara \& S. Ilyas (2017). Efektivitas seed coating dan biopriming dengan rizobakteri dalam mempertahankan viabilitas benih cabai dan rizobakteri selama penyimpanan. Jurnal Hortikultura Indonesia, 8, 192-202.

Nurahmi, E.; Sabaruddin \& N. Erlina (2010). Pengaruh fungisida benlate dan media pengepakan dalam kondisi kelembaban tinggi terhadap vigor dan viabilitas benih kakao setelah penyimpanan. Jurnal Floratek, 5, 140-151.

Pancaningtyas, S. (2013). Perkembangan teknologi kriopreservasi pada tanaman serta peluang penerapannya pada kakao (Theobroma cacao L.). Review Penelitian Kopi dan Kakao, 1, 12-23.

Rahardjo, P. (2011). Menghasilkan Benih dan Bibit Kakao Unggul. Penebar Swadaya, Jakarta.

Rahardjo, P. \& D.F.S Hartatri (2010). Penggunaan acrylic acid sodium acrylate polymer dalam upaya mempertahankan viabilitas benih kakao (Theobroma cacao L.). Pelita Perkebunan, 26, 83-93.

Sari, M.; E. Widajati \& P.R. Asih (2013). Seed coating sebagai pengganti fungsi polong pada penyimpanan benih kacang tanah. Jurnal Agron Indonesia, $41,215-220$

Sumampow, D.M.F. (2010). Viabilitas benih kakao (Theobroma cacao L.) pada media simpan serbuk gergaji. Jurnal Soil Environment, 8, 102-105.

Susilowati, P.E.; A. Fitri \& M. Natsir (2017). Penggunaan pektin kulit buah kakao sebagai edible coating pada kualitas buah tomat dan masa simpan. Jurnal Aplikasi Teknologi Pangan, 6, 1-4. 